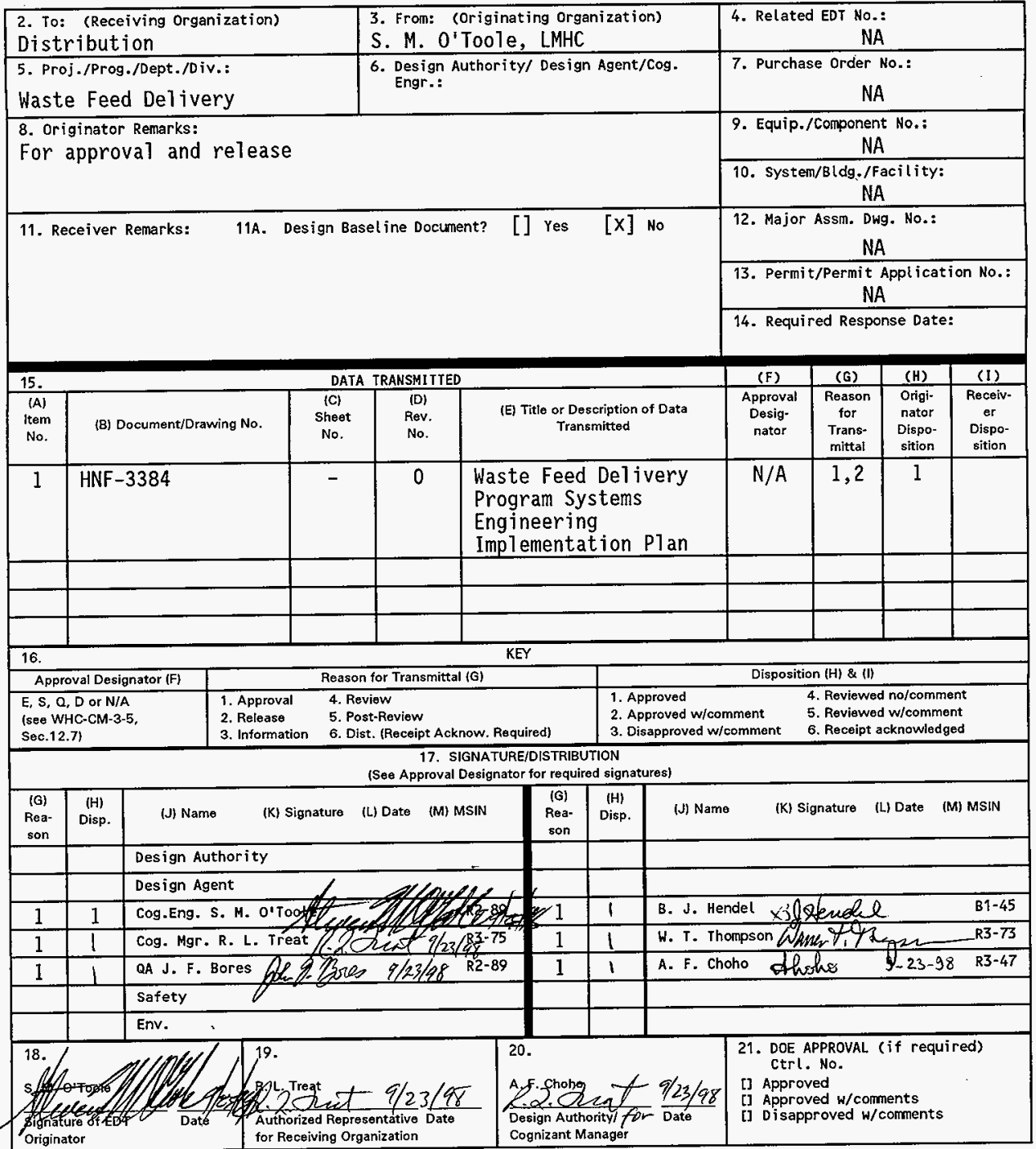

BD-7400-172-2 (05/96) GEF097 


\section{Waste Feed Delivery Program Systems Engineering Implementation Plan}

S. H. O'Toole and B. J. Hendel (TRW)

Lockheed Martin Hanford Corporation, Richland, WA 99352

U.S. Department of Energy Contract DE-AC06-96RL13200

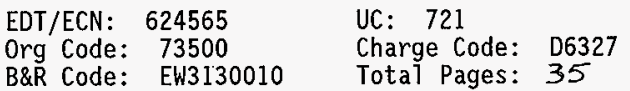

Key Words: waste feed delivery, WFD, SEIP

Abstract: This document defines the systems engineering processes and products planned by the Waste Feed Delivery Program to develop the necessary and sufficient systems to provide waste feed to the Privatization Contractor for Phase 1 . It defines roles and responsibilities for the performance of the systems engineering processes and generation of products.

TRADEMARK DISCLAIMER. Reference herein to any specific comercial product, process, or service by trade name, trademark, manufacturer, or otherwise, does not necessarily constitute or imply its endorsement, recommendation, or favoring by the United States Government or any agency thereof or its contractors or subcontractors.

Printed in the United States of America. To obtain copies of this document, contact: Document Control Services, P.O. Box 950, Mailstop H6-08, Richland WA 99352, Phone (509) 372-2420;

Fax (509) 376-4989.
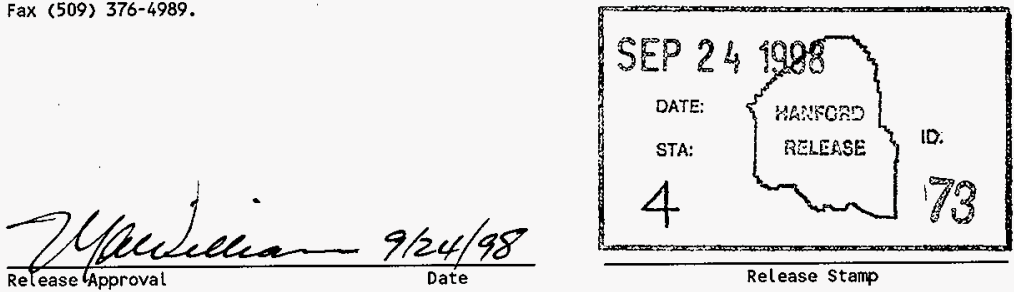

Approved for Public Release 
HNF-3384

Revision 0

\title{
WASTE FEED DELIVERY PROGRAM SYSTEMS ENGINEERING IMPLEMENTATION PLAN
}

September 1998

\author{
S. M. O'Toole \\ Lockheed Martin Hanford Corporation \\ Richland, Washington
}

B. J. Hendel

TRW Environmental Systems

Richland, Washington

Prepared for

U.S. Department of Energy

Richland, Washington 
HNF-3384

Revision 0

This page intentionally left blank. 
HNF-3384

Revision 0

CONTENTS

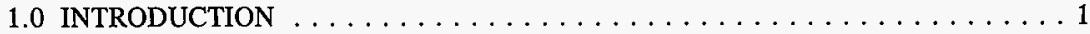

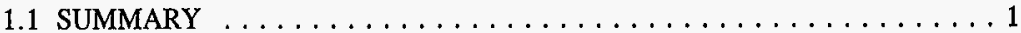

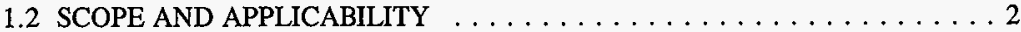

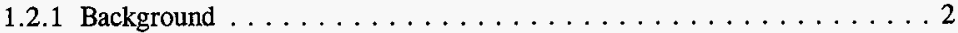

1.2.2 Application of the Systems Engineering Implementation Plan $\ldots \ldots \ldots 3$

1.2 .3 Risks . . . . . . . . . . . . . . . . . . . 4

1.2.4 Component Grading Summary $\ldots \ldots \ldots \ldots \ldots \ldots \ldots \ldots$

1.2.5 Interface With Other Planning Documents $\ldots \ldots \ldots \ldots \ldots \ldots$

2.0 SYSTEMS ENGINEERING MANAGEMENT PROCESS $\ldots \ldots \ldots \ldots \ldots \ldots 7$

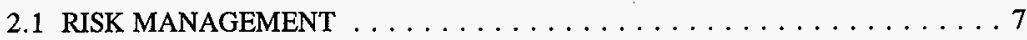

2.2 DECISION MANAGEMENT $\ldots \ldots \ldots \ldots \ldots \ldots \ldots \ldots \ldots \ldots$

2.3 INTERFACE MANAGEMENT $\ldots \ldots \ldots \ldots \ldots \ldots \ldots \ldots$

2.4 CONFIGURATION MANAGEMENT $\ldots \ldots \ldots \ldots \ldots \ldots \ldots \ldots$

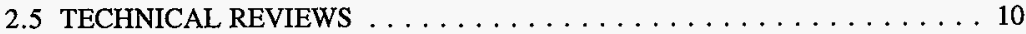

2.6 TECHNICAL PERFORMANCE MEASUREMENT $\ldots \ldots \ldots \ldots \ldots \ldots 11$

2.7 SYSTEMS ENGINEERING PROGRAM EVALUATION $\ldots \ldots \ldots \ldots \ldots 11$

2.8 SYSTEMS ENGINEERING MANAGEMENT PROCESS PRODUCTS, ROLES, AND RESPONSIBILITIES $\ldots \ldots \ldots \ldots \ldots \ldots \ldots \ldots \ldots$

3.0 SYSTEMS ENGINEERING PROCESS $\ldots \ldots \ldots \ldots \ldots \ldots \ldots \ldots \ldots \ldots$

3.1 SYSTEMS ENGINEERING PROCESS $\ldots \ldots \ldots \ldots \ldots \ldots \ldots \ldots \ldots$

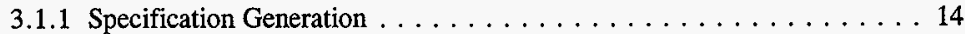

3.1.2 Demonstration Project Definition $\ldots \ldots \ldots \ldots \ldots \ldots \ldots$

3.1 .3 System Assessment . . . . . . . . . . . . . . . 19

3.1.4 Project Definition . . . . . . . . . . . . . . . . . . 19

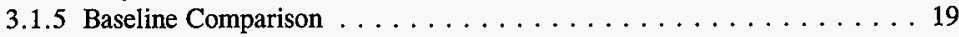

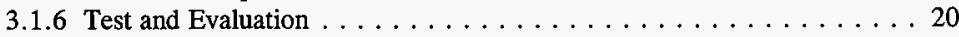

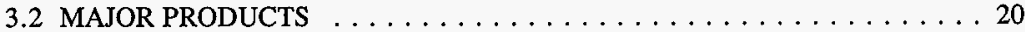

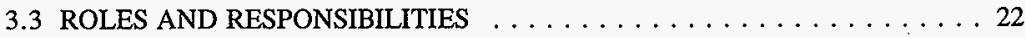

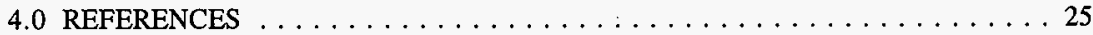


HNF-3384

Revision 0

\section{LIST OF FIGURES}

1-1. Waste Feed Delivery Source Documents $\ldots \ldots \ldots \ldots \ldots \ldots \ldots \ldots$

3-1. Waste Feed Delivery Program Systems Engineering Process. . . . . . . . . 15

\section{LIST OF TABLES}

2-1. Systems Engineering Management Processes Roles and Responsibilities. . . . . . . 12

3-1. Waste Feed Delivery Systems Engineering Technical Documents. . . . . . . . . 20

3-2. Systems Engineering Process Roles and Responsibilities. . . . . . . . . 23 
HNF-3384

Revision 0

\section{LIST OF TERMS}

AGA

CD

CFR

CM

D\&D

DOE

DRD

DST

ES\&H

FDC

FFBD

HSTD

HTWOS

ICD

LMHC

M\&I

MAR

PDC

PDS

PHMC

RAM

RL

S/RIDS

SE

SEIP

SEMP

SSC

SST

T\&E

TBD

TBR

TPM

TWR

TWRS

TWRSO\&UP

WAC

WBS

WFD
Alternatives generation and analysis

Critical Decisions

Code of Federal Regulations

Configuration management

Decontamination and decommissioning

U.S. Department of Energy

Design Review Document

Double-shell tank

Environmental, safety, and health

Functional Design Criteria

Functional Flow Block Diagram

Hanford Site Technical Database

Hanford Tank Waste Operations Simulator

Interface Control Document

Lockheed Martin Hanford Corporation

Management and Integration

Mission Analysis Report

Project Design Criteria

Project Development Specification

Project Hanford Management Contract

Reliability, availability, and maintainability

U.S. Department of Energy Richland Operations Office

Standards/Requirements Identification Document

Systems Engineering

Systems Engineering Implementation Plan

Systems Engineering Management Plan

Systems, structures, and components

Single-shell tank

Test and evaluation

To be determined

Technical Basis Review or To be refined

Technical Performance Measurement

Tank Waste Retrieval

Tank Waste Remediation System

Tank Waste Remediation System Operation and Utilization Plan

Washington Administrative Code

Work Breakdown Structure

Waste Feed Delivery 
HNF-3384

Revision 0

This page intentionally left blank. 
HNF-3384

Revision 0

\section{WASTE FEED DELIVERY PROGRAM SYSTEMS ENGINEERING IMPLEMENTATION PLAN}

\subsection{INTRODUCTION}

Waste Feed Delivery (WFD) Program management is implementing the systems engineering (SE) process to define and manage the program technical baseline. This implementation is in accordance with the process defined by the Tank Waste Remediation System Systems Engineering Management Policy (Kinzer 1997) and by the Tank Waste Remediation System Systems Engineering Management Plan (Peck 1998). The Tank Waste Remediation System (TWRS) Systems Engineering Management Plan (SEMP) defines the products, processes, and procedures used by TWRS to accomplish SE objectives.

This Systems Engineering Implementation Plan (SEIP) is written using a "by exception" approach as recommended by the TWRS SEMP. This SEIP defines and communicates the WFD Program specific SE implementation and will be revised as necessary to reflect the program planning.

\subsection{SUMMARY}

The purpose of this document is to integrate and communicate the Program's implementation of the TWRS SE process including any modifications, exceptions, or differences from the processes defined by the TWRS SEMP. This document defines the SE processes and products planned by the WFD Program to develop the systems to provide waste feed to the Privatization Contractor for Phase 1. It defines roles and responsibilities for the performance of the SE processes and generation of products.

The Hanford 200 Area Tank Farms will be modified and upgraded to carry out the WFD Phase 1 mission of delivering low-activity and high-level waste to the Privatization Contractor. Existing equipment must be evaluated, modifications specified, and new equipment specified to upgrade the system to accomplish this mission. Some of the Tank Farm upgrade work has been initiated and must be integrated with future upgrade work over the next decade. This document provides the framework and processes to define and manage this complex system and the associated risk.

For this document, references to WFD with or without the addition of "program" refers to the WFD Program. When the discussion is directed at the projects associated with WFD, the term WFD projects will be used. 
HNF-3384

Revision 0

\subsection{SCOPE AND APPLICABILITY}

This document defines how WFD employs the SE policies and practices defined in the TWRS SEMP for development and management of the technical baseline for the activities included in Work Breakdown Structure (WBS) 1.01.04.01.01 Deliver Waste Feed for the TWRS Phase 1 waste feed mission. The WFD mission is a subset of the TWRS mission as defined by Tank Waste Remediation System Mission Analysis Report (Acree 1998). The portions of the TWRS Phase 1 mission for which WFD Program has primary responsibility are: tank sequence planning, designing, and constructing facilities that are necessary for waste retrieval, waste preparation, and waste transfer to supply low-activity and high-level waste feed to the Privatization Contractor for processing from selected double-shell tanks (DSTs) and single-shell tanks (SSTs).

\subsubsection{Background}

WFD is currently defining the system to provide waste feed to the Privatization Contractor. The product of this activity will be the baseline set of requirements and architecture decisions to enable the optimized design of new hardware or modification of existing hardware. This approved set of requirements and architectures, referred to herein as the Requirements Baseline, will be used to manage WFD technical activities. TWRS Project and Tank Waste Retrieval (TWR) provide two levels of source documents applicable to the WFD activities as shown in Figure 1-1.

Figure 1-1. Waste Feed Delivery Source Documents.

\begin{tabular}{|c|}
\hline $\begin{array}{l}\text { TWRS Project } \\
\text { TWRS Mission Analysis Report }\end{array}$ \\
\hline $\begin{array}{l}\text { TWR Division } \\
\text { TWRS Operations and Utilization Plan } \\
\text { TWRS Retrieval and Disposal Mission Technical } \\
\text { Baseline Summary Description }\end{array}$ \\
\hline $\begin{array}{l}\text { Waste Feed Delivery Program } \\
\text { Level } 1 \text { Specifications } \\
\text { Level } 2 \text { Specifications } \\
\text { Baseline Comparison Reports } \\
\text { Other Requirements Documents (FDC, PDS, DRD) } \\
\text { System Assessment Reports } \\
\text { Acquisition Plan } \\
\text { Project Design Criteria } \\
\text { etc. }\end{array}$ \\
\hline
\end{tabular}


HNF-3384

Revision 0

The WFD projects will transform this Requirements Baseline into project Design Baselines, and in cooperation with tank farm operations, into the Operational Baseline of equipment, facilities, materials, qualified staff, safety basis, characterization data, and supporting documentation required to support the current safe storage mission and physically deliver the waste to the Privatization Contractor for immobilization. The WFD Requirements Baseline for the TWRS Phase 1 mission is or will be documented by the following:

- System Specification for the DST System

- $\quad$ SST Phase 1 WFD System Specification

- Interface control documents (ICDs)

- Functional Design Criteria (FDC)

- Level 2 specifications

- Project Development Specifications (PDSs).

The WFD Program includes a number of existing projects in varying phases of the project life cycle. These projects and their current project phase are as follows:

- Project W-314 Tank Farm Restoration and Safe Operations ${ }^{1}-$-In Design and Construction Phase

- Project W-211 Initial Tank Farm Retrieval System--In Design Phase

- Project W-320 Tank C-106 Retrieval--In Turnover Phase

- Project W-151 AZ-101 Mixer Pumps--In Turnover Phase

- Project W-521 Name TBD--In Pre-Conceptual Phase

- Project W-522 Phase 1 DST Retrieval Systems--In Pre-Conceptual Phase.

\subsubsection{Application of the Systems Engineering Implementation Plan}

This SEIP will apply to WFD activities required to accomplish the current mission and provide waste feed delivery for the TWRS Phase 1 mission with a focus on initial tasks conducted during the next few years. This document will be updated as required to reflect future planning and implementation.

${ }^{1}$ WFD has programmatic responsibility. By WBS, W-314 is a TW03 Tank Farm Operations project. 
HNF-3384

Revision 0

\subsubsection{Risks}

Major risks for WFD relate to the ability to deliver the necessary quantities, qualities and types of waste to the Privatization Contractor on schedule. These risks have been analyzed and are documented in the TWR Critical Risk Management List. The Critical Risk List has been released twice, the latest as an attachment to the Evaluation of Tank Waste Disposal Alternatives Within Privatization (LMHC-9854671A R1) (Wojtasek 1998). Examples of the WFD risks included on the TWR Critical Risk List are as follows:

- CR-012--Key facilities may not support the mission due to obsolescence, corrosion or wear.

- CR-020--Significant changes in rates of saltwell pumping or waste generated by other facilities could limit the ability to transfer the waste within the DST System.

Section 2.1 expands on the risk analysis process, documentation, and risk management process implemented by the WFD Program.

\subsubsection{Component Grading Summary}

The WFD Program does not directly develop any of the hardware design baselines. The design baselines are the responsibility of the projects. Therefore, the Component Grading Guidelines, Draft, (HNF-IP-0842 Vol. IV Sec. 1.2) do not apply to the WFD Program work scope.

WFD projects will perform Component Grading for their respective systems, structures and components (SSC) and document the results in project-specific SEIPs. Through the projects, the WFD Program will manage SSCs that can range from complex SSCs, with high to moderate risk, to form, fit, and function maintenance replacements.

\subsubsection{Interface With Other Planning Documents}

This SEIP documents the processes planned for use in defining the WFD system. In most cases the processes summarized in this document have separate detailed plans or procedures defining how to accomplish the activities that are referenced herein.

The specific work planned to define, design and build the system is captured in WFD Level 1 Logics and in companion Technical Basis Reviews (TBR). Level 1 Logics are graphical representations showing planned work and relationships between the work for Phase 1. For each block on the logic there is a TBR that includes the following data:

- Work description

- Required enabling assumptions 
HNF-3384

Revision 0

- Requirements and deliverables

- Connection with other organizations

- Required trade studies

- Decisions made or required

- Risk issue risk resolution plan

- Cost estimate

- Schedule milestones.

The Multi-Year Work Plan is the summation of the scope, cost, and schedule data developed using the Logics and TBRs. 


\section{HNF-3384}

Revision 0

This page intentionally left blank. 


\subsection{SYSTEMS ENGINEERING MANAGEMENT PROCESS}

WFD is implementing SE management processes as required by the TWRS SEMP. The processes include: risk management, decision management, interface management, configuration management (CM), technical reviews, technical performance measurement, and SE program evaluation (maturity assessment). WFD is also performing a related management activity for enabling assumptions to ensure the assumptions are documented, tracked and finally closed. This document groups the enabling assumption process description with decision management description. The responsible management level and rigor of the analysis and documentation will be commensurate with the importance of a given risk, decision, enabling assumption, etc.

Data generated from the SE management processes listed above will be stored and maintained in the TWR Information Management System currently being developed. The database tables and fields are linked so the program staff is prompted to consider the related management processes when performing planning, assessing an activity, etc. For example, a prompt will request that risks be identified whenever an enabling assumption is generated. This database is complementary to the Hanford Site Technical Database (HSTD) and the technical data it contains. The management data will be linked to technical data in the HSTD through a common issue description captured in both databases. TBR identification numbers will provide a common reference for the risk, decision, enabling assumption, $\mathrm{CM}$ data, etc. Having a common reference will improve the data correlation and will provide confidence in the completeness of the information. An example of what would be expected from the correlation: an AGA would be planned to close a critical decision. Stated in other terms, the correlation provides a "gap" analysis to determine voids in the related data for any given data element.

\subsection{RISK MANAGEMENT}

WFD will analyze and manage risk in accordance with the Risk Management Procedure (HNF-IP-0842 Vol. IV Sec. 2.6) and the Tank Waste Remediation System Risk Management Plan (Zimmerman 1998). Risks are identified by the projects and the program using a variety of sources, including: issues, enabling assumptions, required decisions, baseline comparison reports, systems assessments, and analysis of activities documented by Level 1 logics and TBRs. These risks are analyzed for consequence and probability, a mitigation action developed and the residual risk determined. These data are used to develop a risk list that is prioritized based on return on investment for the mitigation actions. This ranking provides management visibility as to which mitigating actions provide the greatest risk reduction for the least expenditure of resources.

The program will use risk lists generated from the TWR Integrated Management System as the primary risk management communication tool. After the risks are ranked, some risks will be retained for management at the program level, others will be delegated to the 
appropriate program element or WFD project, or transferred to TWR for management. Risks that are cut across contract boundaries and/or projects will be managed by WFD. WFD provides TWR with risks for inclusion on the TWR Critical Risk List. The TWR Critical Risk List has been released as Tank Waste Retrieval and Disposal Mission Readiness To Proceed Memorandum (HNF-2019, Rev. 1) (Jordan 1998) and was updated in the Evaluation of Tank Waste Disposal Alternatives Within Privatization (LMHC-9854671A R1) (Wojtasek 1998).

WFD will update the risk analysis periodically, nominally quarterly, and revise the WFD risk list as required to document significant changes in the list. The analysis results will be communicated up to TWR and down to the WFD projects. TWR, WFD's parent organization, is developing a series of metrics to measure progress in accomplishing risk management. WFD will implement these metrics when they become available.

\subsection{DECISION MANAGEMENT}

WFD will identify, analyze, document and close decisions in accordance with the Decision Management Procedure (HNF-IP-0842 Vol. IV Sec. 2.7). The specification generation process and the establishment of the requirements baseline identify the majority of the required decisions at the program level (see Section 3.1.1). The Alternative Generation and Analysis Procedure (HNF-IP-0842 Vol. IV Sec. 3.3) provides direction on how to analyze the decision. As part of the analysis process, risks are analyzed and documented.

WFD Decision Documents include the following minimum content: a problem statement, decision date, decision maker, alternative selected, criteria used, assumptions, and alternatives rejected. The level of detail in Decision Documents will vary with the importance of the decision, and will range from one line entries on a one-page decision report for a simple decision to a comprehensive document for a complex and significant decision. Implementation of decisions that impact an ongoing project's technical baseline is addressed in Section 3.1.5.

Currently, TWRS captures the pending decisions in the Technical Decision Status Summary Document (Zimmerman 1998). WFD provides updates as requested, to support the periodic TWRS Projects revisions to the document.

Technical enabling assumptions will be developed so that activities can proceed where factors preclude timely completion of the decision process. Significant technical enabling assumptions will have associated decisions and a closure plan identified. As part of the enabling assumption generation process, risks will usually be identified and analyzed before accepting the enabling assumption. In addition to the TWR Information Management System, a technical enabling assumptions HSTD change request will be generated. A procedure is currently being developed to communicate the details of the Enabling Assumption management processes. 
HNF-3384

Revision 0

\subsection{INTERFACE MANAGEMENT}

WFD will implement an interface control process to define, document and control selected physical, programmatic and organizational interfaces for the program in accordance with the Interface Control Procedure (HNF-IP-0842 Vol. IV Sec. 2.8). WFD will generate HSTD change requests for the physical interface data for interfaces down to the component level. WFD will review and approve the HSTD generated ICDs. WFD provides inputs to the Tank Waste Retrieval Interface List released previously as Identification and Control of TWRS Interfaces (Schaus 1998). This list is a roll up of project and program data. Interfaces with PHMC entities outside of TWRS are managed through the Management and Integration (M\&I) contractor.

WFD will develop a common set of ICDs with DOE and the Privatization Contractor to manage the PHMC/Privatization Contractor interfaces. These ICDs will be managed by DOE/RL using an Integrated Product/Process Team with representation from DOE, the Privatization Contractor, and the PHMC. The requirements and architecture decisions documented in the ICDs will be input into the HSTD and WFD Requirements Baseline as appropriate.

\subsection{CONFIGURATION MANAGEMENT}

The CM approach will be in compliance with the TWRS Configuration Management Plan (Vann 1997) and Configuration Management Implementation Procedure (HNF-IP-0842, Vol. VIII, Sec. 3.1). The CM implementation provides mechanisms to identify, document, and control the functional and physical characteristics of WFD products, in compliance with DOE and site requirements, as derived from Vann (1997). The CM process outputs include: the documented identification of products that need CM control (configuration items and information), the determination of the rigor of $\mathrm{CM}$ control required for each product, and the identification of the mechanisms to achieve the appropriate levels of $\mathrm{CM}$ control. The CM approach focuses on five principal activities, which include: CM system management, configuration item/information identification, configuration status accounting, document control, change control, and $\mathrm{CM}$ assessments.

Configuration Management System Management: The scope of the CM system management is to direct and monitor the development and implementation of the CM program within WFD in accordance with the TWRS CM process guidelines.

Configuration Item/Information Identification: WFD will identify key items and information important to the program's mission, in accordance with Vann (1997). This includes the programmatic and technical baselines and a variety of deliverables as well as SSCs. 
Configuration Status Accounting: CM item and information selection will be documented and entered into the TWRS CM database for control and monitoring. Status accounting of configuration items will be accomplished through this TWRS CM information system that will list and status configuration items and associated configuration information, including the item/information identifier, ownership, and associated WBS element.

Document Control: Documents will be controlled in accordance with HNF-PRO-210, Records Management Program, and HNF-PRO-224, Document Control.

Change Control: Control of changes to the TWRS Project Baseline are delineated in TWRS Change Control, LMHC-MD-004 (Rosenberry 1997). The "A/B/C" change board system will be used by the WFD for baseline management. Changes that affect the Integrated Baseline will be processed and dispositioned in accordance with the TWRS Baseline Change Control Procedure (HNF-IP-0842, Vol. VIII Sec. 1.1).

Programmatic Assessments: WFD management, working with the TWRS Project CM organization and the TWRS Project Quality Assurance organization will perform assessments for compliance to the TWRS Configuration Management Implementation Procedure (HNF-IP-0842, Vol. VIII, Sec. 3.1).

\subsection{TECHNICAL REVIEWS}

WFD will perform technical reviews at the program and project level. The Program level reviews will include management assessments to determine overall system readiness to support the high-level waste and low-activity waste feed mission. These reviews will be led by the program staff with support from the project teams and representatives from other TWRS organizations. The WFD Program manager is the approval authority for the reviews. The project-level reviews include: Project Mission Review, System Functional Review, and design reviews.

Before initiation of a project, the program will perform a Project Mission Review on the project definition data to ensure the project's need, scope, functions, requirements, and alternatives are valid. The WFD Program manager is the approval authority for the review. Results from the Project Mission Review feed the DOE/RL Critical Decision 1 (Approval of Mission Need). WFD is responsible for the PHMC participation in CD 1.

A System Functional Review will be conducted for each project prior to CD-2 by the WFD program. The review will verify the maturity of the projects's technical baseline, cost estimate and schedule prior to approving transition into the design phase. The WFD Program manager is the approval authority for the review. Results from the System Functional Review feed the DOE/RL Critical Decision 2 (Approve Baseline). WFD is responsible for the PHMC participation in $\mathrm{CD} 2$. 
HNF-3384

Revision 0

Project reviews are conducted by the project to ensure the design and constructed facilities comply with requirements. The project manager is the approval authority for the reviews. WFD will participate in the project reviews.

\subsection{TECHNICAL PERFORMANCE MEASUREMENT}

WFD will implement technical performance measurement (TPM) in accordance with the Technical Performance Measurement Procedure (HNF-IP-0842 Vol. IV Sec. 2.4). TPM will be used selectively at the program and project level to provide management visibility on progress in achieving required performance for a particular performance objective for the DST and SST systems. WFD will document the implementation planning results in a TPM Assessment Plan.

\subsection{SYSTEMS ENGINEERING PROGRAM EVALUATION}

TWRS has developed a SE evaluation procedure, the Systems Engineering Maturity Assessment and Compliance Guide (Draft - HNF-IP-0842 Vol. IV Sec. 2.14), to assess the maturity of an organization's SE capability to facilitate self-improvement. WFD will determine the impacts and how best to implement the procedure after it is released.

\subsection{SYSTEMS ENGINEERING MANAGEMENT PROCESS PRODUCTS, ROLES, AND RESPONSIBILITIES}

Table 2-1 defines the responsibilities and approval authorities for the management process products described in Section 2.0. Many of the processes generate hierarchical sets of information. Data at the lowest levels can be approved by the project managers or their designees. However, as data are rolled up, a higher level manager's approval will be required. The table reflects the highest approval required for WFD SE management process data. The WFD Program Manager can delegate approval authority to subordinates at the manager's discretion.

Table 2-1 is based on the following definitions:

- Approvers are those signatories required to release the product.

- One organization has the lead to perform the process, but may have support from multiple organizations.

- Organizations/Positions with review responsibility provide input to the product approvers. 
Table 2-1. Systems Engineering Management Processes Roles and Responsibilities.

\begin{tabular}{|c|c|c|c|c|c|c|c|c|c|}
\hline \multirow[b]{2}{*}{ Management Process Products } & \multicolumn{9}{|c|}{ Organization/position } \\
\hline & $\begin{array}{c}\text { WFD } \\
\text { Program } \\
\text { Manager }\end{array}$ & $\begin{array}{c}\text { WFD } \\
\text { Systems } \\
\text { Engineer }\end{array}$ & $\begin{array}{l}\text { WFD Prog. } \\
\text { Analysis \& } \\
\text { Control }\end{array}$ & $\begin{array}{l}\text { Retrieval } \\
\text { Eng. }\end{array}$ & $\mathrm{ES} \& \mathrm{H}$ & $\begin{array}{l}\text { Ops. \& } \\
\text { Maint. }\end{array}$ & $\begin{array}{l}\text { Project } \\
\text { Integr. } \\
\text { Manager }\end{array}$ & Projects & QA \\
\hline Risk Management & A & $\mathbf{R}$ & $\mathbf{L}$ & $\mathbf{S}$ & $\mathbf{S}$ & $\mathbf{S}$ & $\mathbf{R}$ & $\mathbf{S}$ & $S$ \\
\hline Decision Management & A & $\mathbf{R}$ & $\mathbf{L}$ & $\mathbf{S}$ & $S$ & s & $\mathbf{R}$ & $S$ & $S$ \\
\hline Configuration Management & $\mathrm{A}$ & $\mathbf{R}$ & L & $\mathrm{A}$ & $\mathbf{S}$ & $s$ & $\mathbf{R}$ & $\mathbf{S}$ & A \\
\hline $\begin{array}{l}\text { Architecture Interface } \\
\text { Management }\end{array}$ & A & $\mathbf{R}$ & $\mathbf{S}$ & $\mathrm{L}(1)$ & 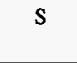 & $s$ & $\mathbf{R}$ & $\mathrm{L}(2)$ & A \\
\hline $\begin{array}{l}\text { Organization Interface } \\
\text { Management }\end{array}$ & A & $\mathbf{R}$ & L & $S(3)$ & $\mathbf{S}$ & $\mathbf{s}$ & $\mathbf{R}$ & N/A & A \\
\hline Project Mission Review & A & $\mathbf{R}$ & $s$ & $\mathrm{~L}$ & $\mathbf{S}$ & $s$ & $\mathrm{~A}$ & N/A & A \\
\hline System Functional Review & A & $\mathbf{R}$ & $s$ & $\mathbf{R}$ & $s$ & $\mathrm{~s}$ & $\mathbf{L}$ & $\mathbf{R}$ & A \\
\hline Project Reviews & $\mathrm{s}$ & $\mathbf{R}$ & $\mathbf{s}$ & $\mathbf{R}(4)$ & $\mathbf{s}$ & $\mathbf{s}$ & $\mathbf{R}$ & $\mathrm{A} / \mathrm{L}$ & $\mathrm{A}$ \\
\hline $\begin{array}{l}\text { Technical Performance } \\
\text { Measurement }\end{array}$ & A & $\mathbf{R}$ & $s$ & $\mathrm{~L}$ & $\mathbf{S}$ & $\mathbf{S}$ & $\mathbf{R}$ & $s$ & $\mathbf{S}$ \\
\hline SE Program Evaluation & A & $\mathrm{L}$ & $\mathbf{R}$ & S & $\mathbf{S}$ & $S$ & $\mathbf{R}$ & $S$ & $\mathbf{S}$ \\
\hline
\end{tabular}

A = Approval

ES\&H = Environmental, safety, and health

$\mathrm{L}=$ Lead on preparation

$\mathrm{n} / \mathrm{a}=$ Not applicable

$\mathrm{R}=$ Review

$S=$ Support

SSC $=$ Systems, structures, and components

WFD $=$ Waste Feed Delivery

Notes

$1=$ System to system

2 = Project to Project, SSC to SSC interfaces

3 = Organization to organization

4 = Reviews by the design authority will be coordinated by WFD Retrieval Engineering. 
HNF-3384

Revision 0

\subsection{SYSTEMS ENGINEERING PROCESS}

This section summarizes the SE process as implemented by the WFD program and the planned SE products that will be developed to document the results. It defines the roles and responsibilities for performing the process and approving the documents. This SEIP adds specificity to the process and product descriptions beyond those contained in the TWRS SEMP.

The WFD program will tailor individual processes for each application based on the complexity and significance of the task. For example, a level 2 specification for a roads upgrade would be less comprehensive than a specification for in-tank hardware.

\subsection{SYSTEMS ENGINEERING PROCESS}

The WFD SE process starts with basis documents from the TWRS Project and TWR including: Tank Waste Remediation System Mission Analysis Report (Acree 1998), the Tank Waste Remediation System Operation and Utilization Plan (Kirkbride et al. 1997) and DOE/RL imposed requirements derived from the Privatization Contract (DE-RP0696RL13308) as part of the fiscal year 1999 Planning Guidance. These documents provide the source requirements for the WFD SE analysis.

The TWRS MAR defines the TWRS Project responsibilities to include nine Major Facilities, two of which constitute the Phase 1 waste feed delivery system. These are the DST System and the SST Major Facilities. A subsequent decision has combined the DST and SST systems into the Tank Farm System Major Facility for accounting purposes, but the separation was retained for system development purposes.

The WFD SE process expands on processes defined in the TWRS SEMP and is currently focused on development of requirements and assessment of ongoing projects and the existing DST and SST systems for suitability to satisfy the Phase 1 waste feed delivery mission. The SE process starts with the TWRS Project and TWR input documents and includes the following:

- Generation of specifications

- Defining and completing demonstration projects to resolve issues

- Assessing the ability of the existing system to satisfy the requirements

- Defining projects to develop new systems or modify existing systems

- Comparing the existing projects technical baselines with the level 1 and level 2 specifications to evaluate the completeness of the project requirements 
- Review and integration of the project designs to ensure the system will satisfy the mission.

The relationships between these activities are shown in Figure 3-1.

\subsubsection{Specification Generation}

Specifications are generated to define and communicate the WFD major facility and project level component requirements. Specification generation activities include the following:

- Analyzing the TWRS level requirements using functional analysis

- Analyzing the requirements including: performance requirements, design constraints and interface requirements

- Analyzing the alternative technologies and design concepts to select the preferred system configuration

- Making decisions

- Planning for test and evaluation.

WFD will generate system specifications (i.e., Level 1) for both the DST and SST systems. The DST System has been categorized into 6 major subsystems and will be further defined through Level 2 specifications. A subsystem Level 2 specification will be generated where a single indenture is sufficient. Where additional detail is required, a series of Level 2 specifications will be generated at the component level. The decision on which architecture elements will be documented through component specifications will be defined in a specification tree.

The SST System specification will focus on the Phase 1 SST retrieval mission to retrieve and transfer the waste from 241-C-102 or 241-C-104, and is referenced in this document as "SST Phase 1 Waste Feed Delivery System Specification". The balance of the SST System requirements will be analyzed and the specification updated at a future date. Because SST Phase 1 Waste Feed Delivery System Specification development is just starting, there is insufficient information to determine what Level 2 specification(s) will be written at this time.

Specification generation activities are iterative in nature, and include feedback loops to allow results of lower level analyses to support the resolution of issues at higher levels. For example, the analysis performed to generate a Level 2 specification can cause revisions to the parent Level 1 specification. After the lower level analysis is completed, any assumed values are verified or revised and the assumptions and issues are closed. 
Figure 3-1. Waste Feed Delivery Program Systems Engineering Process.

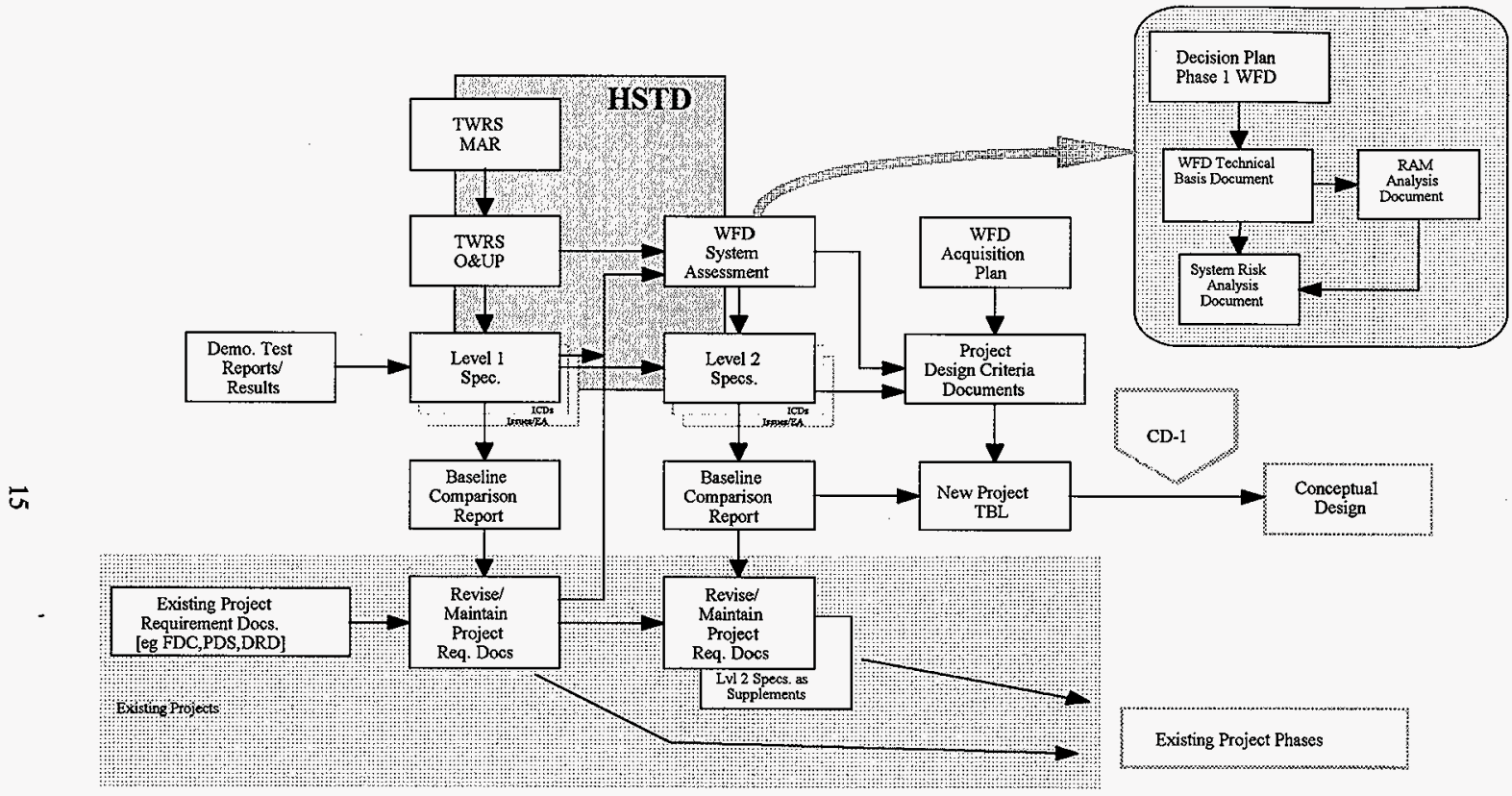

$\mathrm{CD}=$ Critical Decision

$\mathrm{DRD}=$ Design Review Document

$\mathrm{EA}=$ Enabling assumption

FDC $=$ Functional Design Criteria

PDS $=$ Project Development Specifications

RAM $=$ Reliability, availability, and maintainability

TBL $=$ Technical Baseline

TWRS $=$ Tank Waste Remediation System

TWRSO\&UP $=$ Tank Waste Remediation System Operation and Utilization Plan

WFD $=$ Waste Feed Delivery 
Many of the specifications and interface control documents were generated using word processors and the data are now being entered into the HSTD retroactively. For example, the DST System Specification was developed with a word processing software, but the requirements are now maintained in the HSTD and future revisions of the document will be generated from the database. The WFD Program will maintain the specifications (Level 1 and 2) and existing project requirements documents (PDS, FDC, and DRD).

3.1.1.1 Functional Analysis. Functional analysis determines the necessary and sufficient activities the system must perform, and the sequence of those activities to achieve the mission. Functional analysis produces function descriptions, inputs, outputs, and requirements which are captured in the HSTD. The functions are documented graphically using Functional Flow Block Diagrams (FFBD) or other tools that show the logical relationships and interfaces with the other system functions. Functional analysis will be performed per Functions and Requirements Analysis and Allocation and Development of Level 1 and Level 2 Specifications (HNF-IP-0842, Vol. IV, Sec. 3.2).

3.1.1.2 Requirements Analysis. WFD will perform requirements analyses to quantitatively define functional requirements, to determine the applicable requirements imposed by laws, regulations, statutory sources, contracts, procedures and by the interfaces with other systems. These analyses will be documented in referenceable reports that provide requirements traceability. The WFD requirements analyses are categorized as three basic types:

- Performance requirements analysis

- Constraints analysis

- Interface requirements analysis.

Performance requirements analyses are performed following each level of functional analysis to quantify the functional requirements. Source data for these analyses include the functional analysis results, process requirements (i.e, Hanford Tank Waste Operations Simulator (HTWOS) results/TWRSO\&UP [Kirkbride et al. 1997]), and reliability, availability and maintainability (RAM) requirements. The results will be allocated to appropriate functions through a HSTD change request.

Where analysis is insufficient to determine the necessary system performance or the performance of current technology for the application is undefined, an enabling assumption will be generated and a demonstration or test will be planned. This may require the creation of a demonstration project (see Section 3.1.2).

Constraints analysis reviews the laws, regulations, and other statutory requirements to determine the applicability of these requirements to the WFD system. The imposed regulations (e.g., National Environmental Policy Act of 1969, Code of Federal Regulations, Hanford Project Procedures,) provide performance requirements and limitations on how the system is constructed. These requirements need to be reviewed, interpreted and allocated to the SSCs in the HSTD. 
Interface analyses will be performed to establish requirements for the interface between two SSCs. The interface data for systems and components will be reflected in specifications and ICDs. ICDs will be generated in accordance with the Interface Control Procedure (HNF-IP-0842 Vol. IV Sec. 2.8).

WFD is performing analyses to determine the RAM requirements for the specifications. These analyses are based on the system concept documents, including the draft operations and maintenance concept. In addition to providing RAM requirements for the specifications, the results will be reflected in system concept documents to provide guidance to the projects, operations, and maintenance.

To produce a complete requirements set, WFD will include tank farm knowledgeable representatives from the specialty engineering disciplines in the requirements analyses and alternatives studies to evaluate the system concepts documents against qualitative criteria such as constructability, operability, etc. Their inclusion will ensure the system will be easy to build, safe for the workers and public, compliant with government regulations, operable when needed, easy to maintain, and easy to operate, and, when the system is no longer needed, easy to decontaminate and decommission.

3.1.1.3 Alternative generation and analysis. Potential system architectures will be evaluated in accordance with the Alternative Generation and Analysis (AGA) Procedure (HNF-IP-0842, Vol. IV Sec. 3.3). The complexity of AGAs will vary with the complexity and importance of the architecture being selected. Results will be documented in a formal report. The Decision Management Procedure (HNF-IP-0842, Vol. IV, Sec. 2.7) will be used to make the final selection and document the decision resulting from the AGA. The architecture decisions are a major factor in how Section 3.7 of the Level 1 and 2 specifications are organized and provide the next level of definition for the architecture tree (see section 3.1.1.6).

3.1.1.4 Test and Evaluation Planning. WFD will perform test and evaluation planning during the specification generation process to assure the requirements can be verified. The planning covers two different Test and Evaluation (T\&E) analyses. The first, verification analysis will determine what is required to prove that a design and constructed system complies with the applicable specification requirements. The second, validation analysis, will determine how the tools used in the verification process will be proven.

The verification planning analysis is the selection of which method of verification (i.e., examination, analysis, demonstration or test) will be used to prove compliance of the design and final system with the Requirements Baseline. The method of verification will be documented in the Level 1 and 2 specifications and the WFD Program Test and Evaluation Plan.

WFD will conduct validations of the analytical tools used to evaluate and verify the system. For example, the HTWOS is used to predict system performance. The calculations 
behind the model were validated and the results documented in Verification and Validation of the Tank Waste Remediation System Hanford Tank Waste Operations Simulator (Wittman 1997).

3.1.1.5 Evaluation and optimization. The Requirements Baseline and the system assessments will identify opportunities for optimization studies to look for areas of improvement in the overall system. WFD will perform evaluation and optimization activities by looking across the needs of the entire system and balancing requirements generated by different activities developing components. Optimization trade studies will be tailored to support the specific area of evaluation or optimization and will consider the following factors when making trades:

- Technical feasibility/maturity

- Risk

- Life cycle cost

- Reliability and maintainability

- Testability

- Schedule

- Operability impacts

- System effectiveness

- Other specialty engineering.

3.1.1.6 Architecture Trees. After the architecture decisions are completed for the Level 1 specifications, the architecture tree will be updated to document and communicate the hierarchical definition of the system. After the necessary architecture decisions are completed for the Level 2 specifications, the architecture trees will again be updated. This process continues until the system is defined at the lowest level where requirements will be verified.

Architecture trees provide one of the tools for selecting which specifications to generate for the next level of indenture. There will be cases where the architecture tree has more "branches" than the specification tree, but the specification tree will follow the architecture tree.

\subsubsection{Demonstration Project Definition}

Issues that cannot be resolved by analysis during the specification generation process can drive the need for a demonstration project. Demonstration projects are chartered to resolve an issue or issues in order to assure the Requirements Baseline is complete and correct. Demonstration project results will be documented in test reports, project documents, etc., and will provide feedback into the requirements analysis process. This information will be reflected in the specifications as a requirement, often providing the basis for removing a "TBD" or "TBR." Demonstration projects can be created to resolve an issue at any point in the analysis, either for a system specification (Level 1) or a component specification (Level 2). They will vary in length, scope, and complexity depending on the issue(s) being tested. 
HNF-3384

Revision 0

\subsubsection{System Assessment}

Part of the WFD work scope is to assess the existing system and components being developed by ongoing projects to determine what portions have sufficient capability to satisfy the mission requirements without modification. The system assessment process was defined in part by the decision planning documented in the Decision Plan for Establishing an Adequate Phase 1 Waste Feed Delivery System Concept (Claghorn 1998b) and will provide data to close the decision. This process will include review of maintenance records, system walk downs, performance analysis and modeling of the systems, RAM analysis, risk analysis, and in some cases operational tests. The WFD systems assessment will look across the system necessary to deliver a waste feed batch to ensure all parts of the system being developed or modified will work together to accomplish the mission. This activity will determine where gaps that would preclude the safe, efficient and timely accomplishment of the mission exist. This analysis provides a basis for defining architectural interfaces between projects and for defining the scopes of new projects. System Assessment results will be documented in System Assessment Reports including: the WFD Technical Basis Document (updated process flow sheet, design concept, and operations and maintenance concept), RAM analysis reports, and risk analysis reports.

\subsubsection{Project Definition}

Where the existing system is determined to be insufficient to satisfy the mission and current projects do not include the required scope, a new project will be defined to provide new SSCs or modify existing SSCs. In addition, decisions on new projects will be driven by the WFD acquisition strategy which will be documented in the WFD Acquisition Plan. Program staff will perform the pre-conceptual design activities and develop the Project Design Criteria (PDC) and related documentation. This documentation will typically include: project scope, project mission, level 2 specification, ICDs, and operations and maintenance concept. Project personnel will phase into these activities as the personnel are identified and assume responsibility for the project after CD-1. WFD has responsibility for the project activities through CD-1.

\subsubsection{Baseline Comparison}

A number of existing projects are proceeding with design and construction activities in parallel with the WFD Program activities. Project technical baselines will be evaluated against requirements generated by the WFD Program. If differences are found, decisions will be made to accept the risk from the differences or the project baseline will be modified. If a baseline modification is required, the program will revise the project guidance, generate the engineering change notice and revise the existing project requirement documents (i.e., FDC, PDS, DRD). The project will develop the impact assessment and document the results using a 
HNF-3384

Revision 0

baseline change request. The program is responsible for adjustments to funding and schedule to compensate for the impacts of the changes.

\subsubsection{Test and Evaluation}

The results of the WFD Program T\&E planning will be documented in the WFD T\&E Plan. Project specific T\&E planning and required resources will be identified in parallel with conceptual and design activities and documented in a project level T\&E Plan.

The projects have the primary responsibility to conduct the analyses, evaluations, demonstrations and testing to prove the designs and hardware fulfill the specification requirements. The design verification is accomplished through design reviews supported by analysis and test data as necessary. The constructed system is verified through some level of testing (acceptance and operations tests) before turnover. The methods of verification were selected by the $\mathrm{T} \& \mathrm{E}$ planning activity during the specification generation process (see section 3.1.1.4). WFD will review and integrate the project level $T \& E$ activities, and where possible, combine or group tests or analysis to optimize the utilization of resources.

In order to minimize risk of unsuccessful waste feed delivery, the WFD Program will use test and evaluation to ensure the system is operational with the capacity defined by the requirements. WFD will conduct a management assessment of the overall system prior to declaring readiness for delivery of the first waste feed batch.

\subsection{MAJOR PRODUCTS}

The results of the process steps described in Section 3.1 are documented for communication, integration and record purposes. The document types being generated by the WFD Program SE process are listed in Table 3-1. Specific documents are listed as examples of the expected products along with the document release status.

Table 3-1. Waste Feed Delivery Systems Engineering Technical Documents. (3 Sheets)

\begin{tabular}{|l|l|l|}
\hline \multicolumn{1}{|c|}{ Document type } & \multicolumn{1}{|c|}{ Document name } & \multicolumn{1}{|c|}{$\begin{array}{c}\text { Release } \\
\text { status }\end{array}$} \\
\hline \multirow{3}{*}{ Level I Specifications } & $\begin{array}{l}\text { System Specification for the Double Shell Tank System } \\
\text { (HNF-SD-TRD-WM-007) }\end{array}$ & Draft \\
\cline { 2 - 3 } & SST Phase 1 Waste Feed Delivery System Specification & Planned \\
\hline Level 2 Specifications & DST Component Specifications & Planned \\
\hline
\end{tabular}


HNF-3384

Revision 0

Table 3-1. Waste Feed Delivery Systems Engineering Technical Documents. (3 Sheets)

\begin{tabular}{|c|c|c|}
\hline Document type & Document name & $\begin{array}{c}\text { Release } \\
\text { status }\end{array}$ \\
\hline \multirow{2}{*}{$\begin{array}{l}\text { Functional Design } \\
\text { Criteria }\end{array}$} & $\begin{array}{l}\text { Functional Design Criteria, Project W-211, Initial Tank Retrieval } \\
\text { Systems (WHC-SD-W211-FDC-001) }\end{array}$ & Released. \\
\hline & $\begin{array}{l}\text { Tank 101-AZ Waste Retrieval System Function Design Criteria } \\
\text { (HNF-SD-W151-FDC-001) }\end{array}$ & Released \\
\hline $\begin{array}{l}\text { Project Development } \\
\text { Specifications } \\
\text { (Project W-314) }\end{array}$ & $\begin{array}{l}\text { Transfer Piping (HNF-SD-W314-PDS-001) } \\
\text { Valve Pit Manifold (HNF-SD-W314-PDS-002) } \\
\text { Leak Detection (HNF-SD-W314-PDS-003) } \\
\text { Master Pump Shutdown (HNF-SD-W314-PDS-004) } \\
\text { Special Protective Coatings (HNF-SD-W314-PDS-005) }\end{array}$ & Released \\
\hline $\begin{array}{l}\text { Functional Analysis } \\
\text { Documents }\end{array}$ & $\begin{array}{l}\text { Double-Shell Tank System Functions and Requirements Analysis for } \\
\text { Level } 2 \text { Specifications, (HNF-2826) }\end{array}$ & Draft \\
\hline \multirow{3}{*}{ Requirements Analysis } & $\begin{array}{l}\text { Performance Requirements for DST System Phase } 1 \text { Feed Delivery } \\
\text { (HNF-2168) }\end{array}$ & Released \\
\hline & SST dome loading analysis & Planned \\
\hline & Reliability, Availability and Maintainability Analysis & Planned \\
\hline $\begin{array}{l}\text { Alternative Generation } \\
\text { Reports }\end{array}$ & $\begin{array}{l}\text { Phase } 1 \text { Intermediate Waste Feed Staging Systems Design } \\
\text { Requirements (HNF-SD-TWR-AGA-001). }\end{array}$ & Released \\
\hline Trade Study Reports & & $\begin{array}{l}\text { None } \\
\text { Planned }\end{array}$ \\
\hline $\begin{array}{l}\text { Interface Control } \\
\text { Documents }\end{array}$ & $\begin{array}{l}\text { DST System - } 325 \text { Building ICD } \\
\text { DST System - T-Plant ICD } \\
\text { DST System - WESF } \\
\text { DST System - SST } \\
\text { DST System - 242-A Evaporator } \\
\text { Remaining } 21 \text { DST Interfaces } \\
\text { PHMC - DOE - Privatization ICDs (Quantity:26) }\end{array}$ & $\begin{array}{l}\text { Draft } \\
\text { Draft } \\
\text { Draft } \\
\text { Draft } \\
\text { Draft } \\
\text { Planned } \\
\text { In work }\end{array}$ \\
\hline \multirow{8}{*}{$\begin{array}{l}\text { System Assessment } \\
\text { Reports }\end{array}$} & $\begin{array}{l}\text { Evaluation of Tank Waste Transfers at 241-AW Tank Farm (HNF- } \\
\text { 2238) }\end{array}$ & Released \\
\hline & $\begin{array}{l}\text { Evaluation of 241-AN Tank Farm Supporting Phase I Privatization } \\
\text { Waste Feed Delivery (HNF-2938) }\end{array}$ & Draft \\
\hline & $\begin{array}{l}\text { Evaluation of 241-AZ Tank Farm Supporting Phase I Privatization } \\
\text { Waste Feed Delivery (HNF-2941) }\end{array}$ & Draft \\
\hline & Design Concept & In work \\
\hline & Flowsheet & Draft \\
\hline & Operations and Maintenance Concept & Draft \\
\hline & Risk Analysis Reports & Planned \\
\hline & RAM Analysis Reports & Draft \\
\hline $\begin{array}{l}\text { Architecture and } \\
\text { Specification Trees }\end{array}$ & WFD Architecture and Specification Trees & Planned \\
\hline
\end{tabular}


HNF-3384

Revision 0

Table 3-1. Waste Feed Delivery Systems Engineering Technical Documents. (3 Sheets)

\begin{tabular}{|l|l|l|}
\hline \multicolumn{1}{|c|}{ Document type } & \multicolumn{1}{|c|}{ Document name } & \multicolumn{1}{|c|}{$\begin{array}{c}\text { Release } \\
\text { status }\end{array}$} \\
\hline \multirow{4}{*}{$\begin{array}{l}\text { Baseline Comparison } \\
\text { Reports }\end{array}$} & $\begin{array}{l}\text { Defense Nuclear Facility Facilities Safety Board Recommendation 92- } \\
\text { 4, commitments 5.2.1.A and 5.2.1.B, Technical Basis for Project W- } \\
\text { 211., Correspondence number LMHC-9850461 R5 }\end{array}$ & Released \\
\cline { 2 - 4 } & Baseline Comparison Report for W-314 & Planned \\
\hline \multirow{2}{*}{\begin{tabular}{l} 
Project Design Criteria \\
\cline { 2 - 4 }
\end{tabular}} & W-521 Project Design Criteria & Planned \\
\cline { 2 - 3 } $\begin{array}{l}\text { Test and Evaluation } \\
\text { Plans }\end{array}$ & W-522 Phase 1 DST Retrieval Systems Project Design Criteria & Planned \\
\hline
\end{tabular}

DOE $=$ U.S. Department of Energy

DST $=$ Double-shell tank

ICD = Interface control document

PHMC $=$ Project Hanford Management Contractor

RAM = Reliability, availability, maintainability

SST $=$ Single-shell tank

WESF $=$ Waste Encapsulation and Storage Facility

$W F D=$ Waste feed delivery.

\subsection{ROLES AND RESPONSIBILITIES}

Table 3-2 defines the responsibilities and approval authorities for the products described in Section 3.2. Documents at the lowest levels can be approved by the project managers or their designee. However, as data are rolled up, a higher level manager's approval will be required. The table reflects the highest approval required for WFD SE products. The WFD manager can delegate approval authority to subordinates at his discretion.

Table 3-2 is based on the following definitions:

- Approvers are those signatories required to release the document.

- One organization has the lead to prepare the document but may have support from multiple organizations.

- Organizations/Positions with review responsibility provide input to the document approvers.

- As a minimum, all organizations above the approving level will receive the document for information. 
Table 3-2. Systems Engineering Process Roles and Responsibilities.

\begin{tabular}{|c|c|c|c|c|c|c|c|c|c|}
\hline \multirow[b]{2}{*}{$\begin{array}{l}\text { WFD Systems Engineering } \\
\text { Documents }\end{array}$} & \multicolumn{9}{|c|}{ Organization/Position } \\
\hline & $\begin{array}{c}\text { WFD } \\
\text { Program } \\
\text { Manager }\end{array}$ & $\begin{array}{c}\text { WFD } \\
\text { Systems } \\
\text { Engineer }\end{array}$ & $\begin{array}{c}\text { WFD } \\
\text { Program } \\
\text { Analysis and } \\
\text { Control }\end{array}$ & $\begin{array}{c}\text { Retrieval } \\
\text { Engineering } \\
\text { (1) }\end{array}$ & $\mathrm{ES \& H}$ & $\begin{array}{c}\text { Ops. and } \\
\text { Maintenance }\end{array}$ & $\begin{array}{c}\text { Project } \\
\text { Integration } \\
\text { Manager }\end{array}$ & Projects & QA \\
\hline Level 1 Specification & $\mathbf{A}$ & $\mathbf{R}$ & $I$ & $\mathbf{L}$ & $S$ & $\mathbf{S}$ & A & $I$ & $\mathbf{A}$ \\
\hline Level 2 Specification & A & $\mathbf{R}$ & I & $\mathbf{L}$ & $\mathrm{S}$ & $\mathbf{S}$ & A & $\mathbf{R}$ & A \\
\hline Functional Design Criteria & A & $\mathbf{R}$ & I & $\mathbf{L}$ & $S$ & $S$ & A & $\mathbf{S}$ & A \\
\hline $\begin{array}{l}\text { Project Development } \\
\text { Specification }\end{array}$ & A & $\mathbf{R}$ & I & $\mathbf{L}$ & $S$ & $S$ & A & $S$ & A \\
\hline Functional Flow Block Diagrams & I & $\mathbf{R}$ & $S$ & $\mathrm{~A} / \mathrm{L}$ & $S$ & $\mathbf{S}$ & I & N/A & $I$ \\
\hline Requirements Analysis Report & A & $\mathbf{R}$ & $\mathbf{R}$ & $\mathbf{L}$ & $\mathbf{S}$ & $\mathbf{S}$ & A & $\mathrm{N} / \mathrm{A}$ & $\mathbf{R}$ \\
\hline $\begin{array}{c}\text { Alternative Generation and } \\
\text { Analysis Reports }\end{array}$ & A & $\mathbf{R}$ & I & $\mathbf{L}$ & $S$ & $S$ & A & N/A & $\mathbf{R}$ \\
\hline Trade Study Reports & A & $\mathbf{R}$ & I & $\mathbf{L}$ & $\mathbf{S}$ & $S$ & A & N/A & $\mathbf{R}$ \\
\hline ICD - External To WFD & A & $\mathbf{R}$ & $S$ & $\mathbf{L}$ & $\mathbf{S}$ & $\mathbf{S}$ & $\mathbf{R}$ & $\mathbf{S}$ & A \\
\hline ICD - Internal To WFD & I & $\mathbf{R}$ & $S$ & $\mathbf{R}$ & $S$ & $S$ & A & $\mathbf{L}$ & A \\
\hline System Assessment Reports & A & $\mathbf{R}$ & I & $\mathbf{L}$ & $S$ & $S$ & A & I & $\mathbf{R}$ \\
\hline Architecture/Specification Trees & A & $\mathbf{R}$ & I & $\mathbf{L}$ & $S$ & $\mathbf{S}$ & A & I & $\mathbf{R}$ \\
\hline Decision Documents & A & $\mathbf{R}$ & $\mathbf{R}$ & $\mathbf{L}$ & $S$ & $\mathbf{S}$ & $\mathbf{R}$ & N/A & $\mathbf{S}$ \\
\hline Baseline Comparison Reports & A & $\mathbf{R}$ & $\mathbf{R}$ & $\mathbf{L}$ & $S$ & $S$ & A & $\mathbf{R}$ & $\mathbf{S}$ \\
\hline Project Design Criteria & A & $\mathbf{R}$ & $\mathbf{S}$ & $\mathbf{L}$ & $S$ & $S$ & A & $\mathbf{R}$ & $\mathbf{S}$ \\
\hline Test and Evaluation Plan & A & $\mathbf{R}$ & I & $\mathbf{L}$ & $S$ & $S$ & $\mathbf{R}$ & $\mathrm{R}$ & A \\
\hline
\end{tabular}

$A=$ Approval

ES\&H = Environmental, safety, and health

$\mathrm{I}=$ Information

ICD = Interface Control Document

$\mathrm{L}=$ Lead on preparation

N/A = Not applicable

$\mathrm{QA}=$ Quality Assurance

$\mathbf{R}=$ Review

S = Support

$\mathrm{WFD}=$ Waste Feed Delivery.

${ }^{1}$ Reviews by the design authority will be coordinated by WFD Retrieval Engineering. 
HNF-3384

Revision 0

This page intentionally left blank. 
HNF-3384

Revision 0

\subsection{REFERENCES}

DOE Order 430.1, Life Cycle Asset Management Good Practice Guide, U.S. Department of Energy, Washington, D.C.

Acree, C. D., Jr., 1998, Tank Waste Remediation System Mission Analysis Report, HNF-SD-WM-MAR-008, Rev. 3, Lockheed Martin Hanford Corporation, Richland, Washington.

Carlson, A. B., W. L. Willis, and T. R. Benegas, 1998a, Evaluation of 241-AN Tank Farm Supporting Phase I Privatization Waste Feed Delivery, HNF-2938, Rev. A DRAFT, Numatec Hanford Corporation, Richland, Washington.

Carlson, A. B., W. L. Willis, and T. R. Benegas, 1998b, Evaluation of 241-AZ Tank Farm Supporting Phase I Privatization Waste Feed Delivery, HNF-2941, Rev. A DRAFT, Numatec Hanford Corporation, Richland, Washington.

Claghorn, R. D., J. D. Galbraith, and T. B. Salzano, 1997, Alternatives Generation and Analysis for the Phase 1 Intermediate Waste Feed Staging System Design Requirements, HNF-SD-TWR-AGA-001, Rev. 1, Numatec Hanford Corporation, Richland, Washington.

Claghorn, R. D., 1998a, Double-Shell Tank System Functional Analysis for Level 2

Specifications, HNF-2826, Draft, Numatec Hanford Corporation, Richland, Washington.

Claghorn, R. D., 1998b, Decision Plan for Establishing Adequate Phase 1 Waste Feed Delivery System Concept, HNF-2752, Rev. 0, Numatec Hanford Corporation, Richland, Washington.

FDH, 1998a, Records Management Program, HNF-PRO-210, Fluor Daniel Hanford, Inc., Richland, Washington.

FDH, 1998b, Document Control, HNF-PRO-224, Fluor Daniel Hanford, Inc., Richland, Washington.

Grenard, C. E., R. D. Claghorn, R. P. Marshall Jr., and M. A. deLamare, 1998, System Specification for the Double-Shell Tank System, HNF-SD-WM-TRD-007, Draft Rev, D, Numatec Hanford Corporation, Richland, Washington.

Jordan, K. N., 1998, Tank Waste Remediation System Retrieval and Disposal Mission Readiness-To-Proceed Memorandum, HNF-2019, Rev. 1, Lockheed Martin Hanford Corporation, Richland, Washington. 
HNF-3384

Revision 0

Kinzer, J. 1997, Tank Waste Remediation System (TWRS) Systems Engineering Management Policy, (Letter \#97-MSD-193 to President, Fluor Daniel Hanford Company, Richland, Washington, April 9, 1997), U.S. Department of Energy, Richland Operations Office, Richland, Washington.

Kirkbride, R. A., G. K. Allen, P. J. Certa, A. F. Manuel, R. M. Orme, L. W. Shelton, E. J. Slaathaug, R. S. Wittman, and G. T. MacLean and D. L. Penwell (SESC), 1997, Tank Waste Remediation System Operation and Utilization Plan, HNF-SD-WM-SP-012, Rev. 0, Vol. I and II, Numatec Hanford Corporation, Richland, Washington.

LMHC, 1997, TWRS Administration, HNF-IP-0842, Fluor Daniel Hanford, Inc., Richland, Washington.

National Environmental Policy Act of 1969, Public Law, 42 USC 4321 et seq.

Peck, L. G., 1998, Tank Waste Remediation System Systems Engineering Management Plan, HNF-SD-WM-SEMP-002, Rev. 1, Lockheed Martin Hanford Corporation, Richland Washington.

Rosenberry, M. W., 1997, TWRS Change Control, LMH-MD-004, Rev. 0, Lockheed Martin Hanford Corporation, Richland, Washington.

Schaus, P. S., 1998, Identification and Control of TWRS Interfaces, interoffice memo to R. D. Wojtasek, 73600-97-PSS-001 (January 1), Lockheed Martin Hanford Corporation, Richland, Washington.

Treat, R. L., 1998, Tank Waste Remediation System Retrieval and Disposal Mission Technical Baseline Summary Description, HNF-1901, Rev. 0, Lockheed Martin Hanford Corporation, Richland, Washington.

Vann, J. M. 1997, Tank Waste Remediation System Configuration Management Plan, HNF-1900, Rev. 0, prepared by Lockheed Martin Hanford Corporation for Fluor Daniel Hanford, Inc., Richland, Washington.

Willis, W. L., W. A. Peiffer, B. B. Peters, and T. L. Waldo II, Evaluation of Tank Waste Transfers at 241-AW Tank Farm, HNF-2238, Rev. 0, Numatec Hanford Corporation, Richland, Washington.

Wittman, R. S., 1997, Verification and Validation of the Tank Waste Remediation System Hanford Tank Waste Operations Simulator, HNF-SD-TWR-RPT-006, Rev. 0, Numatec Hanford Corporation, Richland, Washington.

Wojtasek, R. D., 1998, Evaluation of Tank Waste Disposal Alternatives within Privatization, LMHC-9854671A R1, Lockheed Martin Hanford Corporation, Richland, Washington. 
HNF-3384

Revision 0

Zimmerman, B. D., 1998a, Tank Waste Remediation System Risk Management Plan HNF-SD-WM-PMP-018, Rev. 2, Lockheed Martin Hanford Corporation, Richland, Washington.

Zimmerman, B. D., 1998b, Technical Decision Status Summary Document, (No Number), Lockheed Martin Hanford Corporation, Richland, Washington. 
HNF-3384

Revision 0

This page intentionally left blank. 


\section{DISTRIBUTION SHEET}

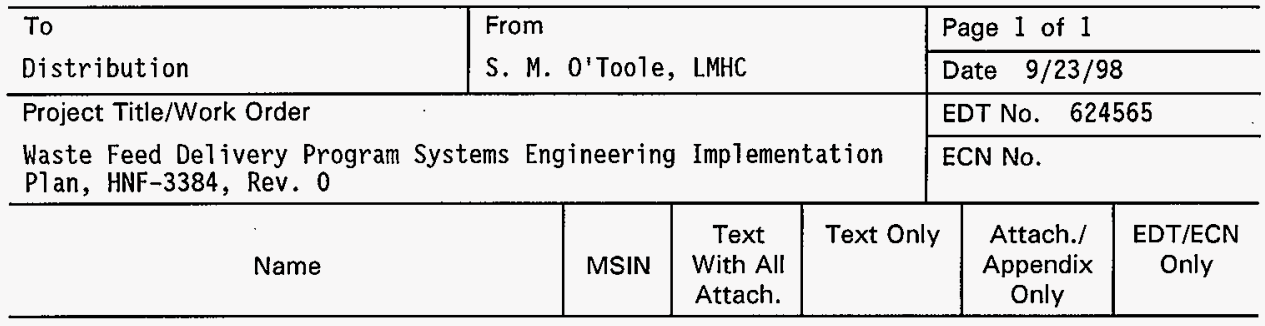

Central Files

DOE Reading Room

DIMC

P. R. Angetier

D. J. Ashley

S. K. Baker

J. F. Bores

H. L. Boston

A. B. Carlson

P. J. Certa

A. F. Choho

R. D. Claghorn

T. J. Conrads

G. L. Crawford

R. D. Crisp

R. A. Dodd

W. J. Eischens

J. D. Galbraith

J. S. Garfield

C. E. Grenard

D. M. Hammond

B. J. Hende?

J. L. Homan

F. A. Jensen

R. D. Jensen

R. A. Kirkbride

M. J. O'Neill

S. M. O'Toole

M. A. Payne

L. G. Peck

R. D. Potter

R. W. Powell

R. E. Raymond

P. S. Schaus

W. J. Stokes

W. T. Thompson

R. L. Treat

J. E. Van Beek

J. M. Vann
B1-07 $X$

H2-53 $X$

Rl-4l $X$

S7-82 $X$

A3-03 $X$

R3-73 $X$

R2-89 X

R2-53 X

R3-73 $X$

R3-73 $X$

R3-47 $X$

R3-73 $X$

H5-25 X

R3-73 $X$

$\mathrm{RI}-04 \quad X$

R3-72 $X$

R3-75 $X$

R3-73 $X$

R3-73 $X$

R3-74 X

R1-44 $X$

B1-45 X

R3-25 $X$

R3-75 $X$

R3-75 $X$

R3-73 $X$

R3-75 $X$

R2-89 $X$

R2-58 $X$

H7-06 X

R3-73 $X$

R3-75 $X$

R3-38 $X$

R2-89 X

R3-75 $X$

G3-21 $X$

R3-75 $X$

S2-48 $X$

$\mathrm{H} 6-37 \quad X$ 